\title{
Personality Berpengaruh terhadap Terjadinya Stress Kerja Perawat di Ruang Rawat Inap Rumah Sakit Umum Kota Salatiga
}

\author{
Serafina Damar Sasanti *), Zahroh Shaluhiyah $\left.{ }^{* *}\right)$ \\ *) Akademi Kebidanan Ar-Rum Salatiga \\ Korespondensi: serafindamarsasanti@yahoo.com \\ **) Magister Promosi Kesehatan Universitas Diponegoro
}

\begin{abstract}
ABSTRAK
Sekitar 50,9\% perawat yang bekerja di empat provinsi di Indonesia tahun 2006 mengalami Stress Kerja. Perawat sering mengalami pusing dan, kelelahan, karena beban kerja yang tinggi. Hal tersebut menyebabkan ketidakhadiran meningkat, menurunnya produktivitas sehingga berdampak pada penurunan mutu pelayanan di rumah sakit. Tujuan penelitian ini adalah untuk mengetahui pengaruh Personality terhadap stres kerja perawat di ruang rawat inap Rumah Sakit Umum Daerah Kota Madya Salatiga. Jenis penelitian yang digunakan adalah expalanatory research dengan pendekatan cross sectional yang melibatkan 149 Perawat ruang rawat inap. Hasil penelitian didapatkan perawat yang mengalami stress kerja adalah perawat yang mempunyai tipe kepribadian A sehingga diharapkan kepada pemegang kebijakan dalam sistem recruitmen memperhatikan tipe kepribadian untuk dapat ditempatkan di tempat yang sesuai.
\end{abstract}

Kata kunci: personality, stress kerja perawat

\section{ABSTRACT}

Approximately $50.9 \%$ of nurses working in four provinces in Indonesia in 2006 suffered Work Stress. Nurses often experience dizziness and fatigue, due to a high workload. This causes increased absenteeism, decreased productivity so that the impact on the quality of hospital services. The purpose of this study was to determine the effect of work stress Personality of the nurse in the inpatient unit District General Hospital Municipality Salatiga. This type of research is expalanatory research with cross sectional study involving 149 inpatient nurses. The result showed nurses who experience job stress is a nurse who has a personality type A which is expected to policy holders in the system toughest of recruits pay attention to the type of personality to be placed in the appropriate places.

Keywords: personality, job stress of nurses

\section{PENDAHULUAN}

Force Survey pada tahun 1990 menemukan adanya 182.700 kasus akibat kerja di Inggris. Sedangkan pada tahun 1995, menurut Survey Of Self Reported Work Related III Health (SWI) di Inggris menyatakan bahwa terdapat kurang lebih 500.000 individu percaya bahwa dirinya menderita gangguan kesehatan akibat Stress di tempat kerjanya. Hasil Survey Statistic kesehatan Australia barat menunjukkan adanya peningkatan kasus akibat Stress kerja yang fantastis yaitu 205 kasus tuntutan hak asuransi gangguan kesehatan akibat Stress di tempat kerja pada kurun waktu 1993/1994 yang bertambah menjadi 380 kasus pada kurun waktu 1994/1995. Pada survey ini juga dinyatakan bahwa pekerja laki-laki kehilangan kirakira 50,8 hari kerja pada setiap kasus tuntutan hak asuransi, sedangkan pekerja 
wanita kehilangan kira-kira 58,5 hari kerja.

Dengan demikian harus diakui bahwa stres akibat kerja merupakan masalah kesehatan kerja yang penting, yang akan menyebabkan penurunan produktivitas kerja secara bermakna

Perawat dalam menjalankan profesinya sangat rawan terhadap stres, kondisi ini dipicu karena adanya tuntutan dari pihak organisasi dan interaksinya dengan pekerjaan yang sering mendatangkan konflik atas apa yang dilakukan serta beban kerja yang berat. Hal ini diperkuat dengan penelitian yang dilakukan oleh Schaufeli (dalam Eviaty, 2005) menunjukkan profesi bidang kesehatan, perawat memiliki tingkat Stress yang lebih tinggi bila dibandingkan dengan dokter dan apoteker. Rachmawati (2001), menyebutkan hasil survey yang dilakukan Persatuan Perawat Nasional Indonesia (PPNI) tahun 2006. Menunjukkan sekitar $50,9 \%$ perawat yang bekerja di empat provinsi di Indonesia mengalami Stress Kerja Perawat. Perawat sering mengalami pusing, lelah, tidak bisa beristirahat karena beban kerja yang tinggi dan menyita waktu. Hasil penelitian Fansiska Dewi tahun 2013 terdapat hubungan yang signifikan antar beban kerja perawat terhadap stress kerja perawat. Beban kerja perawat di rumah sakit meliputi beban kerja fisik dan mental. Beban kerja fisik meliputi mengangkat pasien, memandikan pasien, membantu pasien ke kamar mandi, dan sebagainya. Sedangkan beban kerja yang bersifat mental dapat berupa bekerja dengan Shift atau bergiliran pagi, siang dan malam, kompleksitas pekerjaan, mempersiapkan mental dan rohani pasien dan keluarga terutama bagi yang akan memerlukan operasi atau dalam keadaan kritis. Hasil penelitian Faiqoh 2010 menunjukkan terdapat hubungan signifikan antara shift kerja dengan stress kerja perawat ruang rawat inap di Unit Rawat Inap RSUD Dr. Soegiri Lamongan. Ridwan Harrianto (2009) menyebutkan hasil penelitian yang dilaksanakan oleh Estryn-Behar M.et al pada tahun 1990, menemukan bahwa cuti sakit perawat wanita dan pekerja rumah sakit lainnya mencapai 3080 hari kerja dari total 25.433 hari kerja akibat jadwal kerja malam di rumah sakit.

$$
\text { Rumah Sakit Umum Daerah }
$$

Salatiga merupakan Rumah Sakit pemerintah dengan tipe $\mathrm{B}$, yang menjadi rujukan di daerah Kotamadya Salatiga. Hasil survey menunjukkan pada tahun 2008 jumlah pasien rawat inap RSUD Kota Salatiga adalah, 9,261 pasien, pada tahun 2009 sebanyak 10,294 pasien tahun, 2010 sebanyak 10.246 pasien, tahun 2011 sebanyak 10.768, tahun 2012 sebanyak 10.895 pasien, dengan kapasitas tempat tidur yang tersedia sebanyak 285 tempat tidur dalam 16 ruangan rawat inap, yaitu pavilyun lantai 2, pavilyun lantai 3, 
pavilyun lantai 4, ruang anggrek, melati, dahlia, cempaka, flamboyant 1 , flamboyan 2 , flamboyant 3 , flamboyant 4 , perinatologi, ICU, HCU, One Day Care, dan Ponek lantai 1.

Menurut Malayu Hasibuan dalam bukunya managemen Sumber Daya Manusia (2001), mengatakan stress karyawan muncul akibat kepuasan kerja tidak terwujud, hal ini dapat diketahui dari kedisiplinan, moral kerja dan perputaran tenaga kerja (turn over). Dan dampak stress kerja adalah meningkatnya angka absensi, menurunnya produktivitas yang dapat dilihat melalui mutu pelayanan di rumah sakit. Menurut Hasibuan Malayu (2009), stress karyawan muncul akibat kepuasan kerja yang tidak terwujud, sedangkan indicator kepuasan kerja dapat dilihat dari beberapa hal yaitu, disiplin kerja, moral kerja dan perputaran tenaga kerja. Indikator pertama adalah disiplin kerja. Jika dilihat dari disiplin pegawai khususnya perawat dalam melaksanakan tugas pokok dan fungsi di RSUD Kota Salatiga masih rendah, hal ini terungkap dari hasil wawancara dengan Kabid Keperawatan RSUD Kota Salatiga. Berdasarkan hasil wawancara yang diperoleh masih banyak perawat yang tidak menepati jam kerja atau shift, masih banyak perawat yang datang terlambat sehingga jeda pergantian shift akhirnya kosong, tidak ikut apel maupun tidak masuk kerja. Hal ini diperkuat dari rekap data disiplin pegawai rumah sakit yang diperoleh dari bagian kepegawaian RSUD Salatiga tahun 2013. Disiplin pegawai di RSUD Salatiga dilihat dari dua hal yaitu keikutsertaan dalam apel dan absensi seluruh pegawai yaitu Eselon IIb, Eselon IIIa, Eselon IIIb, Eselon IVa, staf gol III dan IV, staf golongan I dan II, fungsional lain, CPNS/GTT/dr/PTT, dan tenaga kontrak yang dihitung berdasarkan jumlah pegawai yang tidak apel dan tidak masuk kerja serta jumlah keseluruhan hari tidak apel dan tidak masuk kerja. Dari hal tersebut dapat diketahui 1 pegawai tidak ikut apel selama berapa hari dan tidak masuk kerja selama berapa hari. Penjelasan yang diberikan Kasubag kepegawaian RSUD Salatiga rekap dibuat untuk menilai kedisiplinan pegawai dan juga sebagai acuan dalam memberikan insentif tambahan, konsekuensi pegawai yang tidak disiplin adalah tidak mendapatkan insentif, teguran lisan dan tertulis, penundaan gaji berkala ataupun pemberhentian kerja. Di RSUD Salatiga ada kurang dari 10 orang pegawai yang mendapatkan sanksi pemberhentian gaji berkala, kurang lebih 31 orang mendapatkan teguran lisan, 18 orang mendapatkan teguran tertulis.

Masih tingginya sistem senioritas di RSUD Kota Salatiga dimana dokter spesialis menempati urutan paling tinggi disusul dokter umum, kemudian tenaga paramedic seperti perawat atau bidan 
menyebabkan suasana kerja yang tidak nyaman. Karena adanya sistem senioritas ini akan menyebabkan stress kerja khususnya perawat, misalnya pada saat visite dokter, tidak jarang perawat dimarahi di depan pasien menunjukkan tidak ada kerja sama dalam menyelesaikan pekerjaan, sehingga situasi kerja tidak nyaman.

Pergerakan keluar masuknya karyawan yang cukup tinggi mengindikasikan karyawan tidak betah bekerja karena permasalahan organisasi ataupun individu karyawan. Dari data perpindahan karyawan khususnya perawat yang berstatus pegawai negeri didapatkan kenaikan jumlah di tiap tahunnya. Tahun 2010 sebanyak 3 orang, tahun 2011 sebanyak 6 orang, tahun 2012 sebanyak 7 orang dan tahun 2013 sebanyak 9 orang. Turnover tenaga kerja dapat diukur dengan TOTK = Jumlah keseluruhan pengunduran diri karyawan per bulan/tahun: Jumlah ratarata karyawan dalam daftar gaji perusahaan x 100. Penerimaan karyawan RSUD Kota Salatiga tidak dapat dilakukan setiap tahun, untuk penerimaan mandiri Rumah sakit harus mendapatkan ijin dari pemerintah Kota Salatiga, dan disetujui oleh Dewan Perwakilan Rakyat Kota Salatiga. Pelamar harus melalui tahapan seleksi administrasi, seleksi tes tulis, seleksi wawancara pendahuluan, tes kesehatan dan wawancara lanjutan yang membutuhkan waktu yang panjang. Sedangkan untuk tenaga honorer ditentukan oleh pemerintah daerah.

Ketidakpuasan terhadap pelayanan perawat juga ditemukan dengan adanya beberapa keluhan yang disampaikan pasien melalui kotak saran yang disediakan di RSUD Kota Salatiga. Kesan terhadap perawat yang ditulis pelanggan antara lain, perawat tidak ramah, ketus dan tidak cekatan. Wawancara peneliti pada bulan Desember 2013 dengan beberapa orang pasien dan beberapa keluarga pasien, pasien ataupun keluarga merasa kurang nyaman dengan perawatan yang diberikan karena perawatnya lambat, kurang ramah dan kurang jelas dalam memberikan informasi. Perawat yang bekerja di RSUD Kota Salatiga mempunyai beban kerja yang cukup berat, karena selain memberikan asuhan keperawatan kepada pasien, juga harus membersihkan peralatan medis, menyelesaikan administrasi dan juga mengisi pendokumentasian asuhan keperawatan. Perawat RSUD Kota Salatiga dituntut untuk mengisi dokumentasi asuhan keperawatan secara lengkap dan sesuai standar, hal ini dirasakan menyita waktu dan menghambat pelayanan, perawat memanfaatkan waktu istirahat dengan mengisi dokumentasi asuhan sehingga waktu istirahat dirasakan tidak optimal. Nyeri lambung akibat makan tidak teratur juga dikeluhkan beberapa perawat RSUD Kota Salatiga. Sakit kepala dan nyeri 
pinggang juga sering dialami setelah shift malam. Pada bulan November 2013, sejumlah 13 perawat datang ke pelayanan penyakit dalam dengan gangguan pencernaan dan hipertensi. Bulan Desember sejumlah 9 perawat datang ke pelayanan kebidanan, 23 ke pelayanan penyakit dalam, 7 ke pelayanan ortodentisdi poliklinik Eksekutif. Hal ini patut diduga menjadi salah satu indikator terjadinya Stress pada perawat di RSUD Salatiga. Sehingga perlu diperhatikan, faktor apa sajakah yang menyebabkan Stress pada perawat, dan bagaimana cara perawat menangani stres yang ada, karena apabila dibiarkan tanpa daya upaya untuk menangani dengan tepat maka akan memberikan dampak penurunan kinerja yang akan mempengaruhi penurunan mutu pelayanan rumah sakit.

Lazarus berpendapat bahwa stress terjadi bila terdapat kesenjangan, ketidakseimbangan antara tuntutan dan kemampuan, dengan kata lain stress terjadi pada seseorang mendapatkan tuntutan internal atau eksternal yang melampaui sumber daya yang dimiliki. Tuntutan adalah segala elemen fisik, psikososial dan situasi yang harus dihadapi individu melalui tindakan fisik ataupun mental untuk menyesuaikan diri. Frustasi, ancaman, konflik, tekanan, dan penilaian merupakan bentuk tuntutan pemicu stress. Penilaian merupakan proses penting yang mengantarai individu dengan lingkungan dalam memandang sebuah tuntutan internal maupun eksternal. Individu satu berbeda dengan individu yang lain dalam memberikan penilaian terhadap sebuah tuntutan, menganggap tuntutan sebagai sesuatu yang melukai, mengancam atau sebagai suatu tantangan. Dalam memberikan penilaian karakteristik individu yang berpengaruh yaitu komitmen dan keyakinan. Kontrol diri, kepribadian, harga diri merupakan karakteristik individu yang menentukan kerentanan psikologis individu terhadap situasi yang dapat menimbulkan stress yang bersumber dari dalam individu, organisasi dan pekerjaan ataupun dari lingkungan. Karakteristik tersebut juga menentukan bagaimana cara individu mengatasi tuntutan internal atau eksternal. Keseluruhan penjabaran diatas menimbulkan keinginan peneliti untuk menganalisa faktor yang menyebabkan stress perawat di ruang rawat inap Rumah Sakit Umum Daerah Kota Salatiga karakteristik individu yaitu kepribadian.

\section{METODE}

Jenis penelitian ini adalah jenis penelitian kuantitatif analitik yaitu penelitian yang bertujuan tidak hanya mengidentifikasikan variabel saja tetapi sudah sampai melihat atau menganalisis hubungan atara variabel bebas dengan variabel terikat. Desain penelitian 
menggunakan cross sectional yaitu suatu penelitian untuk mempelajari dinamika korelasi antara faktor resiko dan efek, dengan cara pendekatan, observasi atau pengumpulan data sekaligus pada suatu saat (point time approach), artinya setiap subjek penelitian hanya diobservasi sekali saja dan pengukuran dilakukan terhadap status karakter atau variabel subjek pada saat pemeriksaan Populasi dalam penelitian ini adalah seluruh perawat yang melaksanakan asuhan keperawatan di ruang rawat inap RSUD yang berjumlah 149 perawat. Besar sampling dalam penelitian ini adalah total sampling dimana semua anggota populasi diambil semua menjadi sampel penelitian yaitu sejumlah 149 perawat.

\section{HASIL DAN PEMBAHASAN}

Hasil penelitian menunjukkan bahwa dari 149 responden umur responden yang paling banyak adalah berumur $<45$ tahun yaitu sebesar 134 orang (89,9\%) sedangkan yang berumur $\geq 45$ tahun sebesar 15 orang $(10,1 \%)$. Hal ini menunjukkan bahwa sebagian besar responden termasuk dalam usia produktif yang sangat stabil dan mantap mengambil keputusan serta merasa punya tanggung jawab sehingga bekerja secara bersungguh-sungguh.

Umur responden

Hasil analisis bivariat menunjukkan analisis hubungan antara umur responden dengan stress kerja diperoleh gambaran bahwa responden yang mengalami stress berat pada responden yang berusia $<45$ tahun adalah 52,2\% lebih besar dari responden yang berumur $\geq 45$ tahun yaitu sebesar 33,3\%. Sebaliknya responden yang mengalami stress ringan lebih besar pada yang berumur $\geq 45$ tahun yaitu sebesar $66,7 \%$, disbanding dengan yang berumur < 45 tahun sebesar 47,8\%.Bila dilihat dari hasil uji ststistik menggunakan uji chi square dengan menggunakan tingkat kesalahan $(\alpha)$ 0,05 diperoleh p-value $=0,264$ yang berarti tidak ada hubungan antara umur dengan stress kerja perawat. Umur merupakan factor yang dapat mempengaruhi terjadinya stress kerja. Pekerja dengan umur yang lebih tua akan mempunyai pengalaman yang tidak dimiliki oleh pekerja dengan umur yang relative lebih muda. Pengalaman ini sangat berguna terutama dalam menangani stressor yang terjadi di lingkungan kerja. Umur yang lebih muda secara psikologis sulit beradaptasi dengan stressor yang ada. Namun dalam penelitian ini. Stress kerja adalah respon tubuh yang sifatnya non spesifik terhadap setiap tuntutan beban atasnya, misalnya bagaimana respon tubuj seseorang manakala yang bersangkutan mengalami pekerjaan yang berlebihan. Bila ia sanggup mengatasinya artinya tidak ada gangguan fungsi organ tubuh, maka dikatakan yang bersangkutan tidak mengalami stress. Tetapi sebaliknya bila 
ternyata mengalami gangguan pada satu atau lebih fungsi organ tubuh mengakibatkan seseorang tidak lagi dapat menjalankan tugasnya dengan baik, maka disebut stres. Dalam penelitian ini tidak adanya hubungan antara umur dengan stress kerja perawat. Hal ini menunjukkan bahwa teori Wener, 1993 yang mengatakan stressor fisik dapat berupa usia atau umur tidak sesuai dengan hasil penelitian ini. Sesuai dengan hasil penelitian bahwa usia tidak menjadi factor penyebab stress karena stress dapat terjadi kepada perawat usia berapapun tergantung sisi pandang individu dalam menyelesaikan suatu masalah.

Jenis kelamin

Hasil penelitian menunjukkan bahwa dari 149 responden sebagian besar responden berjenis kelamin perempuan sejumlah 120 orang $(80,5 \%)$, dan yang berjenis kelamin laki laki sejumlah 29 orang $(19,5 \%)$. Hal ini menunjukan bahwa jenis kelamin perawat Rumah Sakit Umum Kota Salatiga mayoritas perempuan, sesuai dengan kebutuhan bahwa perawat perempuan lebih fleksibel dalam melakukan tindakan keperawatan. Hasil penelitian menunjukkan analisis hubungan antara jenis kelamin responden dengan stress kerja diperoleh gambaran bahwa responden yang mengalami stress berat pada responden yang berjenis kelamin perempuan adalah 53,3\% lebih besar dari responden yang berjenis kelamin laki-laki yaitu sebesar 37,9\%. Sebaliknya responden yang mengalami stress ringan lebih besar pada laki-laki yaitu sebesar 62,1\%, dibanding dengan yang perempuan $<45$ tahun sebesar $47,8 \%$. Pada penelitian ini perempuan mempunyai kecenderungan mengalami stress lebih besar, dimana di dalam tubuh seorang perempuan terjadi perubahan hormonal. Perempuan lebih mudah mengalami perasaan bersalah, cemas, peningkatan bahkan penurunan nafsu makan. Saat stress perempuan lebih mudah untuk sedih, sensitive, marah serta mudah menangis. Penurunan estrogen perempuan akan berpengaruh terhadap emosi. Karakteristik perempuan yang mengedepankan emosional daripada rasional ketika menghadapi suatu masalah membuat perempuan cenderung lebih stress dibandingkan laki-laki. (Badan Penelitian dan Pengembangan Departemen Kesehatan RI (2007) Bila dilihat dari hasil uji statistik menggunakan uji chi square dengan menggunakan tingkat kesalahan $(\alpha)$ 0,05 diperoleh $p$-value $=0,200$ yang berarti tidak ada hubungan jenis kelamin dengan stress kerja perawat. Peneliti berpendapat tidak adanya hubungan antara jenis kelamin dengan stress kerja dalam penelitian ini karena perawat laki-laki dan perempuan di ruang rawat inap mempunyai beban kerja yang sama dalam memberikan asuhan keperawatan.

\section{Pendidikan}


Hasil penelitian menunjukkan bahwa dari 149 responden sebagian besar responden masuk kategori pendidikan diploma sebanyak 90 orang $(60,4 \%)$ dan yang mempunyai pendidikan sarjana sebanyak 59 orang atau $(39,6 \%)$. Pendidikan adalah salah satu sarana belajar untuk mengembangkan kecerdasan emosional. Individu mulai dikenalkan dengan berbagai macam bentuk emosi dan bagaimana mengelola emosi melalui pendidikan, sehingga tahu cara menghadapi stressor dan mekanisme koping yang dipakai. Pendidikan formal memberikan bekal yang berguna bagi individu agar mampu beradaptasi di dunia kerja. Perbedaan latar belakang pendidikan sering sekali menjadi penyebab terdapatnya perbedaan dalam cara berfikir dan menangani masalah. Hasil analisi bivariat menunjukkan analisis hubungan antara pendidikan responden dengan stress kerja diperoleh gambaran bahwa responden yang mengalami stress berat pada responden yang berpendidikan sarjana adalah 50,8\% lebih besar dari responden yang berpendidikan diploma yaitu sebesar $50,0 \%$. Sebaliknya responden yang mengalami stress ringan lebih besar pada yang berpendidikan diploma yaitu sebesar $50,0 \%$, dibanding dengan sarjana sebesar 49,2\%.Dalam penelitian ini pendidikan sarjana lebih banyak mengalami stress, hal ini bertentangan dengan penelitian Cohen
(2006) dalam Armen Hareyan yang menunjukkan semakin rendah tingkat pendidikan yang dimiliki seseorang maka semakin tinggi tingkat hormone stress yang dimiliki.Hal ini dikarenakan perbedaan latar belakang pendidikan seseorang menyebabkan pembedaan dalam hal kesempatan untuk menduduki posisi atau jabatan, sehingga dapat menjadi potensi pemicu stress kerja. Di RSUD Kota Salatiga perawat yang mempunyai pendidikan sarjana menduduki posisi atau jabatan tertentu, seperti menjadi kepala ruang sehingga mempunyai tanggung jawab dan beban kerja yang berbeda dan cenderung lebih banyak dibandingkan dengan perawat yang mempunyai tingkat pendidikan diploma. Bila dilihat dari hasil uji ststistik menggunakan uji chi square dengan menggunakan tingkat kesalahan $(\alpha)$ 0,05 diperoleh $p$-value $=1,000$ yang berarti tidak ada hubungan antara pendidikan dengan stress kerja perawat. Peneliti berpendapat bahwa tidak adanya hubungan antara pendidikan dengan stress kerja perawat ruang rawat inap RSUD Kota Salatiga adalah dengan melihat apa yang diungkapkan oleh Notoadmodjo (2003) yang menyatakan pendidikan merupakan proses penyampaian informasi kepada seseorang untuk mendapatkan perilaku. Sedangkan menurut Gilies (1996), Sumber stress pada perawat adalah merawat pasien kasus terminal, konflik antar pegawai, tidak 
adekuatnya staf dan tidak jelasnya harapan diri perawat, jadi tidak berhubungan antara pendidikan dengan stress kerja dikarenakan stress kerja disebabkan karena kondisi lingkungan kerjanya.

\section{Personality}

Hasil penelitian menunjukkan bahwa dari 149 responden sebagian besar responden masuk kategori tipe kepribadian A sebanyak 83 orang $(55,7 \%)$ dan yang mempunyai tipe kepribadian B sebanyak 66 orang atau (44,3\%). Tipe kepribadian merupakan salah satu faktor yang dapat mempengaruhi terjadinya stress kerja. Hal ini berkaitan dengan bagaimana cara seseorang dalam memberikan respon terhadap stressor, baik stressor yang berasal dari lingkungan maupun dari dalam individu tersebut Hasil penelitian bivariat menunjukkan analisis hubungan antara tipe kepribadian responden dengan stress kerja diperoleh gambaran bahwa responden yang mengalami stress berat pada responden yang mempunyai tipe kepribadian A adalah $69,9 \%$ lebih besar dari responden yang mempunyai tipe kepribadian $\mathrm{B}$ yaitu sebesar $38,9 \%$. Sebaliknya responden yang mengalami stress ringan lebih besar pada yang mempunyai tipe kepribadian B yaitu sebesar 74,2\%, dibanding dengan tipe kepribadian A sebesar 30,1\%.Bila dilihat dari hasil uji ststistik menggunakan uji chi square dengan menggunakan tingkat kesalahan $(\alpha)$ 0,05 diperoleh p-value
$=0,000$ yang berarti ada hubungan antara personality dengan stress kerja perawat. Hal ini sejalan dengan penelitian Suriani Ismail, dkk (2013), di RSU Bahteramas Provinsi Sulawesi Tenggara. Adanya hubungan antara tipe kepribadian dengan stress kerja perawat berhubungan dengan sifat yang ada pada individu atau perawat dengan tipe kepribadian A yang memiliki sifat agresif, tidak sabar, perfeksionis, ambisi yang tinggi, mudah bermusuhan. Sifat sifat tersebut menyebabkan individu dengan kepribadian tipe A lebih rentan stress dibandingkan dengan individu yang berkepribadian B.

Dari hasil analisis variabel bebas yang mempunyai pengaruh terhadap variabel terikat yaitu personality. Hal ini sesuai dengan teori stress Lazarus, bahwa internal stressor yang berupa personal, atau karakter individu merupakan salah satu faktor yang paling besar dalam menyumbang terjadinya stress. Menurut teori trait, kepribadian dasar tertentu menentukan karakteristik seseorang dalam berbagai situasi, dari hari ke hari, sampai tahap tertentu dalam hidupnya. Penelitian longitudinal block tentang individu menunjukkan konsistensi karakteristik kepribadian cukup tinggi yang berhubungan dengan stress. Dari penelitian tersebut didapati adanya korelasi yang signifikan yang menggambarkan adanya konsistensi kepribadian, khususnya pada 
karakterisrik kepribadian tertentu yaitu tipe A atau B. Meskipun memang ditemukan juga adanya individu yang memperlihatkan perubahan kepribadian yang cukup dramatis, perubahan tersebut didorong oleh kenyataan bahwa hidup adalah perjuangan sehingga banyak orang berusaha mengembangkan potensi dengan cara menjejaki peran dan perilaku yang baru. Dua komponen utama dari pola perilaku tipe A adalah ketidak sabaran dan ketidak ramahan. Study terhadap 3.308 pria dan wanita kulit putih yang dilakukan oleh National Institutes of Health mempelajari efek dari tipe A, depresi, dan kegelisahan terhadap resiko fisik jangka panjang. Komponen tipe A diukur pada periode tahun dasar dan diukur kembali 15 tahun kemudian. Setelah 15 tahun, partisipan yang berada dalam kuartil kekerasan tertingi memiliki 84 persen resiko lebih tinggi menderita stress dan hipertensi.

Keiv \& Kohan menggambarkan tipe A sebagai individu yang mempunyai derajat dan ambisi yang tinggi, dorongan yang kuat untuk mencapai hasil dan penghargaan kompetitif serta agresif, mempunyai kompulsif untuk bekerja berlebihan. Sedangkan tipe B digambarkan sebagai individu yang santai. Tipe A memiliki sifat yang agresif, mau menentang terhadap yang lain untuk mendapatkan apa yg diinginkan, memiliki standart yang sangat tinggi terhadap dirinya sendiri, bekerja secara berlebihan dengan kecepatan yang luar biasa, suka bersaing dan selalu terpacu dengan waktu. Tipe B cenderung mempunyai perasaan yang tertekan, bekerja dengan lamban, bicara dengan teratur dan santai, sabar dan memiilki daya saing yang rendah. Dari berbagai pendapat yang dikemukakan diatas dapat disimpulkan bahwa individu dengan tipe kepribadian A cenderung agresif, tidak sabar, perfeksionis, ambisi yang tinggi dan polyphastic. Sedangkan tipe B cenderung tidak agresif, sabar, non perfeksionis, ambisi yang rendah dan non polyphastic.

\section{SIMPULAN}

Persentase terbanyak adalah responden yang berumur $<45$ tahun $(89,9 \%)$, jenis kelamin terbanyak adalah perempuan $(80,5 \%)$, pendidikan terbanyak adalah diploma $(60,4 \%)$, perawat yang mempunyai tipe kepribadian $\mathrm{A}$ sebanyak $(55,7 \%)$ perawat yang mempunyai harga diri rendah $(51 \%)$, perawat yang mempunyai Ekternal locus control, (53,7\%), Stressor terbanyak berasal dari lingkungan pekerjaan $(52,3 \%)$, perawat mengalami stress kerja berat sebesar $(50,3 \%)$. Stress kerja berat dialami oleh sebagian besar perawat yang berumur kurang dari 45 tahun (52,2\%), perempuan $(53,3 \%)$, pendidikan sarjana (50,8\%), mempunyai tipe kepribadian A 58 $(69,9)$, mempunyai self Esteem rendah $(53,9 \%)$, tipe Eksternal locus control (71,3\%), stressor organisasi dan pekerjaan $(71,8 \%)$ dan memiliki strategi koping emotion focus coping (92,3\%). Personality atau tipe kepribadian $(\mathrm{OR}=$ 12,403). Hal ini berarti bahwa Personality tipe 
A akan memiliki kemungkinan terjadinya stress kerja lebih besar 12,403 kali dibandingkan dengan perawat yang mempunyai tipe kepribadian B. Mengigat sebagian besar perawat mengalami stress kerja berat, diharapkan kepada pemegang kebijakan di RSUD Kota Salatiga diharapkan menempatkan tipe kepribadian A ditempat yang sesuai dan dapat menanggulangi stress yang terjadi, sehingga dapat mencegah meningkatnya stress pada perawat yang bekerja di Ruang Rawat Inap menurunkan Turn Over dan memperbaiki mutu pelayanan.

\section{KEPUSTAKAAN}

Danang Sunyoto. 2012. Teori, Kuesioner, dan Analisis Data Sumber Daya Manusia (PraktikPenelitian). CetakanPertama. CAPS (Center for Academic Publishing Service). Yogyakarta.

Depkes RI. 2005. Standard dan Modul PelatihanTeknis Perhitungan Unit Cost Pelayanan Kesehatan Pemberi Pelayanan Kesehatan (PPK) Primer $J P K$. Jakarta.

Endin Nasrudin. 2010. Psikologi Manajemen. Cetakan Pertama. CV Pustaka Setia. Bandung

Eviaty dan Satiadarma. 2005. Persepsi Terhadap Dukungan Rekan Sekerja dan Gejala Burn Out (studi pada perawat Unit Perawatan Intensif). Jurnal Pronesisvol 7.no 2. Fakultas Psikologi Taruma Negara. Jakarta.

Faikoh. 2010.Hubungan Shiff Kerja Dengan Stress Kerja Pada Perawat Di Ruang Rawat Inap Rumah Sakit Umum
Daerah Soegiri Lamongan. Jurnal vol.03, No.VII, Des 2010. Surabaya. FKM Unair.

Fransiska Dewi. 2013. Hubungan Beban Kerja Perawat Dan Stress Kerja Perawat Di Ruang Rawat Inap Rumah Sakit Menggala.Jurnal vol 8, No. X. FKM. Lampung .Universitas Esa Unggul.

Hartono. 2010. Management Pemasaran RumahSakit. Rineka Cipta. Jakarta.

Jane Ogden. 1996. Health Psychology A Textbook. Open University Press. Philadelphia.

Jess Feist and Gregory J. Feist. 2010. Teori Kepribadian. Edisi Tujuh. Salemba Humanika. Jakarta.

John, M. Ivancevich. Dkk. Perilaku Dan Management Organisasi. Jakarta. Erlangga.

Jonathan Sarwono. 2006. Metode Penelitian Kuantitatif dan Kualitatif. Edisi Pertama. Grahailmu. Yogyakarta

Khaerul Umam. 2010. Perilaku Organisasi. CetakanPertama. CV Pustaka Setia. Bandung

Michael A. Hogg and Graham M. Vaughan. 1995. Social Psychology An Introduction. Prentice Hall of Australia Pty Limited. Australia.

Malayu S. P. Hasibuan. 2009. Manajemen Sumber Daya Manusia. Cetakan Ketiga Belas. PT Bumi Aksara. Jakarta. Paul T.P. Wong and Lilian C.J Wong. 2006. Handbook of Multicultural Perspectives on Stress and Coping. Springer Science, Business Media, Inc. New York. 
Potter and Perry. 2005. Buku Ajar Fundamental

Keperawatan. Edisi Empat. Buku Kedokteran EGC. Jakarta.

Rita L. Atkinson, dkk. 1983. Pengantar Psikologi. Edisi Kedelapan. Erlangga. Jakarta.

Ridwan Harrianto. 2009. Buku Ajar Kesehatan Kerja. Kedokteran EGC. Jakarta.

Saifuddin Azwar. 2005. Metode Penelitian. Cetakan Keenam. Pustaka Pelajar. Yogyakarta.
Sukma Nolo Widyawati. 2012. Konsep Dasar Keperawatan. Cetakan Pertama. PT Prestasi Pustakaraya. Jakarta.

Sumber Laporan SieYandaru. 2012. Dinas Kesehatan Kota Salatiga. Salatiga

Soekidjo Notoatmojo. 2010. Metode Penelitian Kesehatan. Rineka Cipta. Jakarta.

Zulfan Saam dan Sri Wahyuni. 2012. Psikologi Keperawatan. Cetakan Pertama. PT Rajagrafindo Persada. Jakarta. 